\title{
New insights into the BzdR-mediated transcriptional regulation of the anaerobic catabolism of benzoate in Azoarcus sp. CIB
}

\author{
Gonzalo Durante-Rodríguez,† M. Teresa Zamarro,† José L. García, \\ Eduardo Díaz and Manuel Carmona
}

\begin{abstract}
Correspondence
Manuel Carmona

mcarmona@cib.csic.es
\end{abstract}

Received 6 July 2007

Revised 6 September 2007

Accepted 11 September 2007

\author{
Departamento de Microbiología Molecular, Centro de Investigaciones Biológicas-CSIC, \\ Ramiro de Maeztu 9, 28040 Madrid, Spain
}

\section{INTRODUCTION}

Since aromatic compounds are widely distributed in the environment, they are a common carbon source for microorganisms (Harwood \& Parales, 1996). As many ecosystems are often anoxic, the anaerobic catabolism of aromatic compounds by micro-organisms is important in the global biogeochemical cycles (Gibson \& Harwood, 2002; Lovley, 2003). Benzoate has been used as a good model compound for studying the anaerobic catabolism of aromatic compounds. Benzoate is a common carbon source in nature that is funnelled directly to the widely distributed benzoyl-coenzyme A (benzoyl-CoA) central pathway (Carmona \& Díaz, 2005; Gibson \& Harwood, 2002; Harwood et al., 1999). As a general rule, microorganisms first activate benzoate to benzoyl-CoA, which is then converted to aliphatic intermediates through aromatic ring reduction, $\beta$-oxidation-like reactions and ring cleavage as the main steps. The biochemistry of the benzoyl-CoA central pathway has been well studied in some facultative anaerobic bacteria such as Rhodopseudomonas palustris, Azoarcus evansii and Thauera aromatica (Boll, 2005; Gibson \& Harwood, 2002; Harwood et al., 1999) and to a lesser extent in strict anaerobes such as Desulfococcus multivorans (Peters et al., 2004), Geobacter metallireducens (Carmona \& Díaz, 2005; Wischgoll et al., 2005) and Syntrophus aciditrophicus (Elshahed et al., 2001; Peters et al., 2007). Moreover, molecular microbial ecology studies suggest that the ability to degrade aromatic compounds

†These authors contributed equally to this work.

Abbreviation: RNAP, RNA polymerase. under anaerobic conditions is more widespread among bacteria than previously thought (Jahn et al., 2005; Safinowski et al., 2006; Song \& Ward, 2005). In contrast to the current knowledge on the biochemistry of the anaerobic benzoyl-CoA central pathway, few studies have been conducted to unravel the regulatory circuits that control the expression of the cognate genes, being mainly restricted to the regulation of the bad genes in Rhodopseudomonas palustris and the bzd genes in Azoarcus sp. CIB (Barragán et al., 2005; DuranteRodríguez et al., 2006; Egland \& Harwood, 1999, 2000; Peres \& Harwood, 2006). In the latter organism, the $b z d$ catabolic genes are organized as a single operon (bzdNOPQMSTUVWXYZA) controlled by the $P_{N}$ promoter (López Barragán et al., 2004) and the bzdR gene, which is located immediately upstream of the catabolic operon and encodes the transcriptional repressor BzdR (Barragán et al., 2005). The BzdR-mediated repression of $P_{N}$ is alleviated by the inducer benzoyl-CoA, the first intermediate of the catabolic pathway (Barragán et al., 2005) (Fig. 1). The BzdR protein is the prototype of a new subfamily of transcriptional regulators that exhibit a peculiar modular architecture. Thus, whereas the Nterminal region of BzdR (residues 1-130) shows significant similarity with members of the helix-turn-helix (HTH)XRE family of transcriptional regulators (SMART release; available at http://smart.embl-heidelberg.de/), the C-terminal region (residues 131-298) shows similarity with shikimate kinases (PFAM accession no. PF01202) (Barragán et al., 2005). Although the BzdR subfamily of transcriptional regulators is actively growing, and currently BzdR-like proteins can be identified by sequence comparison analyses in benzoate degradation clusters of over 30 
(a)

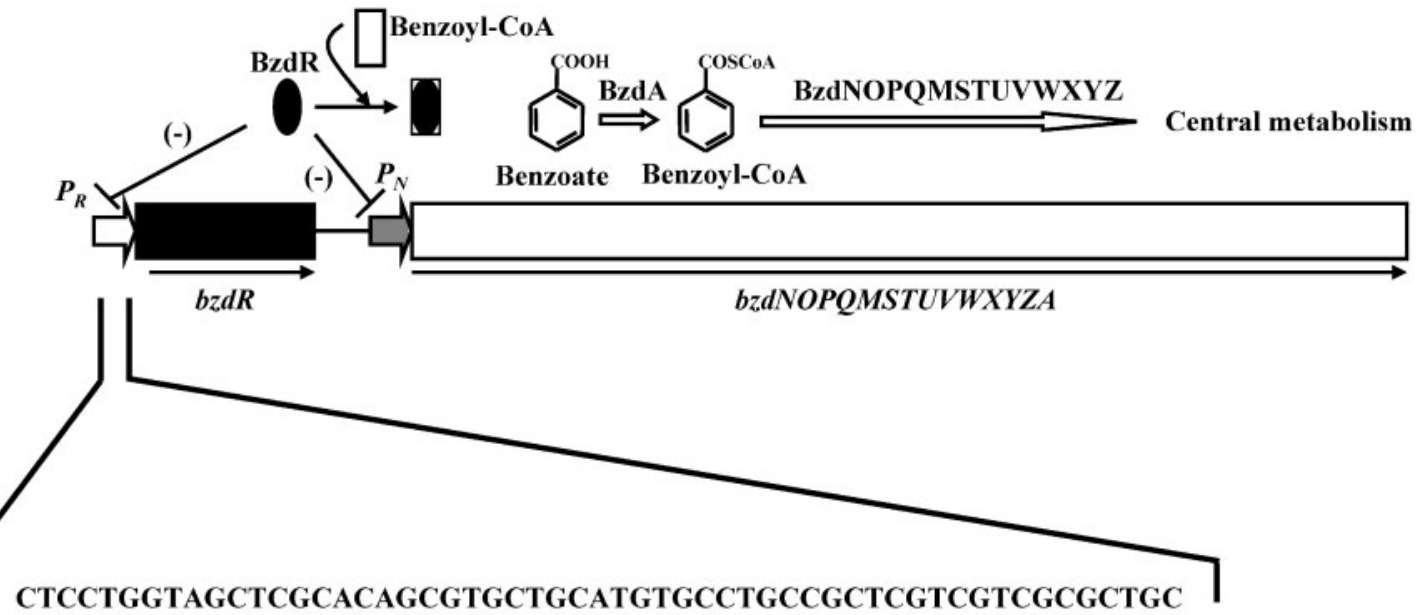

TTGAGCTCGGAGTTTTTCGCGGTTCATGACGTTCATCTGCCGGTGTAGTCATGAAT

GATGCCATATGCATTATCCGGCGTCTCCTGCTTAGGCGTGAGAGCGCTCGCGGGC

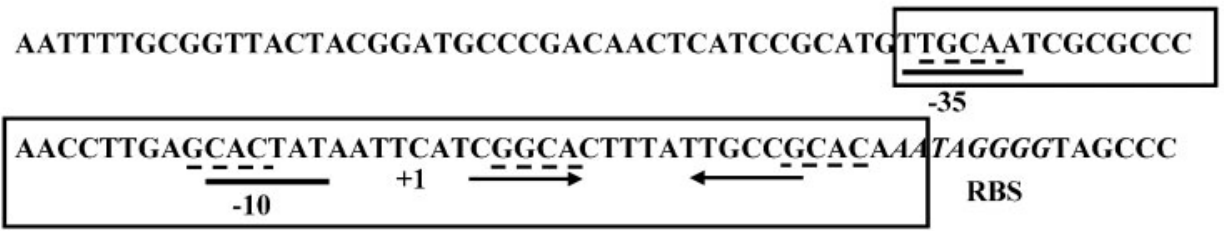

CGATG

bzdR $\longrightarrow$

Fig. 1. Scheme of the bzd cluster and $P_{R}$ promoter from Azoarcus sp. CIB. (a) The bzdR regulatory gene and the bzdNOPQMSTUVWXYZA catabolic operon are shown as black and white boxes, respectively. The $P_{R}$ and $P_{N}$ promoters are indicated as thick white and grey arrows, respectively. The BzdR protein is represented as a black ellipse; benzoyl-CoA is represented as a white rectangle. The minus signs indicate repression of $P_{R}$ and $P_{N}$ by the BzdR protein. The ellipse within the rectangle represents a BzdR protein that is not able to repress the $P_{R}$ or the $P_{N}$ promoters. In the anaerobic catabolism of benzoate, this molecule is first activated to benzoyl-CoA by a benzoate-CoA ligase (BzdA) and is channelled to the central metabolism of the cell through a central pathway that involves the products of the genes bzdNOPQMSTUVWXYZ. (b) Expanded view of the $P_{R}$ promoter. The nucleotide sequence from position -241 to +42 is shown. The transcription start site $(+1)$ and the inferred -10 and -35 boxes of the $P_{R}$ promoter are indicated. The ribosome-binding site (RBS) and the ATG start codon of the $b z d R$ gene are shown in italic and bold letters, respectively. The BzdR-binding region (operator) is boxed. The TGCA and GCAC sequences within the operator region are underlined with a discontinuous line. A short palindromic structure is indicated by convergent arrows.

denitrifying proteobacteria from the $\alpha$ and $\beta$-subgroups, to our knowledge there have been no reports on the expression of any of the $b z d R$ genes.

It is well known that expression of aromatic catabolic clusters is usually tightly controlled. Superimposed upon the specific regulation there is an additional control that links the induction of the pathway genes to the physiological status of the cell (Cases \& de Lorenzo, 1998, 2005; Díaz \& Prieto, 2000; Morales et al., 2004; Tropel \& van der Meer, 2004). In this context, it has been recently shown that the $P_{N}$ promoter activity in Azoarcus sp. CIB is strictly dependent on the AcpR transcriptional activator, an orthologue of the Fnr global regulator of E. coli that specifically controls the oxygen-dependent expression of the bzd catabolic operon (Durante-Rodríguez et al., 2006). On the other hand, carbon catabolite repression is one of the most fundamental environmental-sensing mechanisms in bacteria and imparts competitive advantage by establishing priorities in carbon metabolism. The term catabolite repression describes a number of regulatory processes that ensure that when the cell is exposed to a preferred carbon source, the catabolic pathways for other, non-preferred, substrates are not induced, even when the appropriate inducers are present (Magasanik, 1970). Whereas catabolite repression of pathways for the aerobic catabolism of 
aromatic compounds is well documented (Collier et al., 1996; Ohtsubo et al., 2006; Prieto et al., 2004; Rojo \& Dinamarca, 2004), only a couple of examples of this phenomenon have been reported for the anaerobic degradation of aromatic compounds in T. aromatica (Heider et al., 1998) and Azoarcus sp. CIB (López Barragán et al., 2004), and there are no studies on the molecular mechanisms that control such catabolite repression.

In this work we have studied the regulatory circuit that drives the expression of a gene encoding a transcriptional regulator (BzdR) of a catabolic operon involved in anaerobic degradation of aromatic compounds. Moreover, we provide genetic evidence that the BzdR repressor is also required for the catabolite repression exerted by some carbon sources on the anaerobic benzoate-degradation pathway in Azoarcus sp. CIB.

\section{METHODS}

Strains, plasmids, and growth conditions. The Escherichia coli and Azoarcus strains, as well as the plasmids used in this work, are listed in Table 1. E. coli cells were grown at $37{ }^{\circ} \mathrm{C}$ on Luria-Bertani (LB) medium (Miller, 1972). Azoarcus strains were grown at $30^{\circ} \mathrm{C}$ on MC medium as described previously (López Barragán et al., 2004). Where appropiate, antibiotics were added at the following concentrations: ampicillin, $100 \mu \mathrm{g} \mathrm{ml}^{-1}$; gentamicin, $7.5 \mu \mathrm{g} \mathrm{ml}^{-1}$; kanamycin, $50 \mu \mathrm{g} \mathrm{ml}^{-1}$.

Molecular biology techniques. Recombinant DNA techniques were carried out by published methods (Sambrook \& Russell, 2001).
Plasmid DNA was prepared with a High Pure plasmid isolation kit (Roche Applied Science). DNA fragments were purified with GeneClean Turbo (Q-BIOgene). Oligonucleotides were supplied by Sigma. All cloned inserts and DNA fragments were confirmed by DNA sequencing with an ABI Prism 377 automated DNA sequencer (Applied Biosystems). Transformation of E. coli was carried out by using the $\mathrm{RbCl}$ method or by electroporation (Gene Pulser; Bio-Rad) (Sambrook \& Russell, 2001). Plasmids were transferred from E. coli

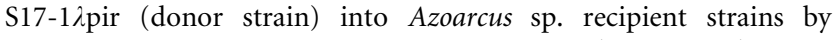
biparental filter mating as described previously (López Barragán et al., 2004). Proteins were analysed by SDS-PAGE (Laemmli, 1970). The protein concentrations in cell extracts were determined by the method of Bradford (1976) using BSA as the standard.

$\boldsymbol{\beta}$-Galactosidase assays. $\beta$-Galactosidase activities were measured with permeabilized cells as described by Miller (1972). Experiments were repeated at least three times for each sample.

Sequence data analyses. Sequence comparison analyses with the Azoarcus sp. strain EbN1 complete genome dataset were done using the TBLAST algorithm (Altschul et al., 1990) at the National Center for Biotechnology Information server (http://www.ncbi.nlm.nih.gov/ BLAST/BLAST.cgi).

Purification of $\mathbf{H i s}_{\mathbf{6}}-\mathbf{B z d R}$. The recombinant plasmid pQE32$\mathrm{His}_{6} \mathrm{BzdR}$ (Table 1) was used for the overproduction of the Histagged BzdR protein in E. coli strain M15 harbouring plasmid pREP4 (Table 1) as described previously (Barragán et al., 2005).

Gel retardation assays. The DNA fragment used for gel retardation assays $\left(P_{R}\right.$ probe) was PCR amplified from plasmid pECOR7 (Table 1) by using oligonucleotides $5^{\prime} \mathrm{PR}$-ScaI (5'-AAAAGTACTCGCGGTTCATGACGTTCATCTG-3'; an engineered $S c a$ I site is underlined)

Table 1. Bacterial strains and plasmids used in this work

\begin{tabular}{|c|c|c|}
\hline Strain or plasmid & Relevant phenotype and/or genotype & Reference or source \\
\hline \multicolumn{3}{|l|}{ E. coli } \\
\hline DH5 $\alpha$ & $\begin{array}{l}\text { endA1 hsdR17 supE44 thi-1 recA1 gyrA }\left(\mathrm{Nal}^{\mathrm{r}}\right) \text { relA1 } \Delta(\operatorname{argF-lac}) U 169 \text { depR } \phi 80 \mathrm{~d} l a c \\
\Delta(\text { lacZ }) \mathrm{M} 15\end{array}$ & Sambrook \& Russell (2001) \\
\hline 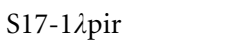 & $\mathrm{Tp}^{\mathrm{r}} \mathrm{Sm}^{\mathrm{r}}$, recA thi hsdRM ${ }^{+} \mathrm{RP} 4:: 2-\mathrm{Tc}:: \mathrm{Mu}:: \mathrm{Km} \mathrm{Tn} 7$ pir phage lysogen & de Lorenzo \& Timmis (1994) \\
\hline M15 & Strain for regulated high-level expression with $\mathrm{pQE}$ vectors & Qiagen \\
\hline \multicolumn{3}{|l|}{ Azoarcus sp. CIB } \\
\hline CIB & Wild-type strain & López Barragán et al. (2004) \\
\hline CIBd $b z d R$ & $\mathrm{Km}^{\mathrm{r}}$, Azoarcus sp. CIB with a disruption of the $b z d R$ gene & López Barragán et al. (2004) \\
\hline $\operatorname{CIBd} b z d N$ & $\begin{array}{l}\mathrm{Km}^{\mathrm{r}} \text {, Azoarcus sp. CIB with a disruption of the } b z d N \text { gene; does not express the } b z d \\
\text { catabolic operon }\end{array}$ & Barragán et al. (2005) \\
\hline \multicolumn{3}{|l|}{ Plasmids } \\
\hline pQE32- His $_{6}$ BzdR & $\begin{array}{l}\text { Ap }{ }^{\mathrm{r}}, \mathrm{pQE} 32 \text { derivative harbouring the } \mathrm{His}_{6}-b z d R \text { gene under the control of the T5 } \\
\text { promoter lac operator }\end{array}$ & Barragán et al. (2005) \\
\hline pECOR7 & $\mathrm{Ap}^{\mathrm{r}}, \mathrm{pUC} 19$ containing a $7.1 \mathrm{~kb} E c o \mathrm{RI}$ DNA fragment from $\lambda \mathrm{Bzd} 1$ & López Barragán et al. (2004) \\
\hline $\mathrm{pSJ} 3 \mathrm{P}_{\mathrm{R}}$ & $\begin{array}{l}\mathrm{Ap}^{\mathrm{r}} \text {, oriColE1, contains the } P_{R} \text { promoter driving the expression of the lac } Z \text { gene } \\
\left(P_{R}:: \text { lac } Z \text { fusion }\right)\end{array}$ & López Barragán et al. (2004) \\
\hline pBBR1MCS-5 & $\mathrm{Gm}^{\mathrm{r}}$, oripBBR1MCS $\mathrm{Mob}^{+}$lacZ $\alpha$, broad-host-range cloning and expression vector & Kovach et al. (1995) \\
\hline pBBR5P $P_{N}$ & $\mathrm{Gm}^{\mathrm{r}}$, pBBR1MCS-5 derivative harbouring a $P_{N}::$ lac $Z$ translational fusion & Barragán et al. (2005) \\
\hline pBBR5P $P_{R}$ & $\begin{array}{l}\mathrm{Gm}^{\mathrm{r}} \text {, pBBR1MCS-5 derivative harbouring the } P_{R}:: \operatorname{lac} Z \text { translational fusion as a } 3.8 \mathrm{~kb} \\
\text { EcoRI-HindIII fragment from } \mathrm{pSJ} 3 \mathrm{P}_{\mathrm{R}}\end{array}$ & This work \\
\hline pREP4 & $\mathrm{Km}^{\mathrm{r}}$, expresses the lacI repressor & Qiagen \\
\hline pJCD01 & $\mathrm{Ap}^{\mathrm{r}}$, oriColE1, polylinker of pUC19 flanked by $r p o C$ and $r r n B T 1 T 2$ terminators & Marschall et al. (1998) \\
\hline $\mathrm{pJCD}-\mathrm{P}_{\mathrm{R}}$ & $\begin{array}{l}\mathrm{Ap}^{\mathrm{r}}, \text { pJCD01 derivative harbouring a } 298 \mathrm{bp} S m a \mathrm{I}-E c o \text { RI fragment that includes the } P_{R} \\
\text { promoter }\end{array}$ & This work \\
\hline
\end{tabular}


and 3'PR-EcoRI (5'-CGGAATTCCGCCCAACATCAGCAGGTAGTTG-3'; an engineered $\overline{\text { EcoRI site }}$ is underlined). The amplified DNA was then digested with ScaI and EcoRI restriction enzymes, and the resulting 298 bp fragment was singly $3^{\prime}$-end labelled by filling in the overhanging EcoRI-digested end with $\left[\alpha_{-}{ }^{32} \mathrm{P}\right] \mathrm{dATP}$ and the Klenow fragment of E. coli DNA polymerase as reported previously (Barragán et al., 2005). The retardation reaction mixtures in FP buffer (20 mM Tris/ $\mathrm{HCl}, \mathrm{pH} 7.5,10 \%$ glycerol, $2 \mathrm{mM} \beta$-mercaptoethanol and $50 \mathrm{mM} \mathrm{KCl}$ ) contained $0.05 \mathrm{nM}$ DNA probe, $500 \mu \mathrm{g} \mathrm{BSA} \mathrm{ml} l^{-1}$ and purified $\mathrm{His}_{6}$-BzdR protein in a final volume of $9 \mu$. After incubation of the retardation mixtures for $20 \mathrm{~min}$ at $30{ }^{\circ} \mathrm{C}$, the mixtures were analysed by electrophoresis in $5 \%$ polyacrylamide gels buffered with $0.5 \times$ TBE ( $45 \mathrm{mM}$ Tris/borate, $1 \mathrm{mM}$ EDTA). The gels were dried on Whatman $3 \mathrm{MM}$ paper and exposed to Hyperfilm MP (Amersham Biosciences).

DNase I footprinting assays. The DNA probe used for DNase I footprinting assays was the same as that reported for the gel retardation assays (see above). For the assays, the reaction mixture contained $2 \mathrm{nM}$ DNA probe, $1 \mathrm{mg} \mathrm{BSA} \mathrm{ml} \mathrm{m}^{-1}$ and purified protein in $15 \mu \mathrm{FP}$ buffer (see above). This mixture was incubated for $20 \mathrm{~min}$ at $37{ }^{\circ} \mathrm{C}$, after which $3 \mu \mathrm{l}$ (0.05 units) of DNase I (Amersham Biosciences) (prepared in $10 \mathrm{mM} \mathrm{CaCl}, 10 \mathrm{mM} \mathrm{MgCl}, 125 \mathrm{mM}$ $\mathrm{KCl}$ and $10 \mathrm{mM}$ Tris/ $\mathrm{HCl}, \mathrm{pH} 7.5$ ) was added, and the incubation was continued at $37{ }^{\circ} \mathrm{C}$ for $20 \mathrm{~s}$. The reaction was stopped by the addition of $180 \mu \mathrm{l}$ of a solution containing $0.4 \mathrm{M}$ sodium acetate, $2.5 \mathrm{mM}$ EDTA, $50 \mu \mathrm{g}$ calf thymus DNA ml${ }^{-1}$ and $0.3 \mu \mathrm{g}$ glycogen $\mathrm{ml}^{-1}$. After phenol extraction, DNA fragments were analysed as previously described (Barragán et al., 2005). A+G Maxam and Gilbert reactions (Maxam \& Gilbert, 1980) were carried out with the same fragments and loaded on the gels along with the footprinting samples. The gels were dried on Whatman 3MM paper and exposed to Hyperfilm MP (Amersham Biosciences).

In vitro transcription assays. Transcription assays were performed by a published procedure (Carmona \& Magasanik, 1996). A 298 bp DNA fragment containing the $P_{R}$ promoter was PCR amplified from plasmid pECOR7 (Table 1) by using oligonucleotides 5' PR-ScaI and 3'PR-EcoRI (see above), and it was cloned into the SmaI/EcoRIrestricted pJCD01 cloning vector (Marschall et al., 1998), yielding plasmid pJCD- $\mathrm{P}_{\mathrm{R}}$ (Table 1). Reactions (50 $\mu \mathrm{l}$ mixtures) were

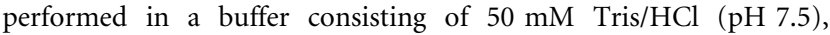
$50 \mathrm{mM} \mathrm{KCl}, 10 \mathrm{mM} \mathrm{MgCl}_{2}, 0.1 \mathrm{mM}$ BSA, $10 \mathrm{mM}$ dithiothreitol and $1 \mathrm{mM}$ EDTA. Each DNA template $(0.5 \mathrm{nM}$ of supercoiled plasmid pJCD- $\mathrm{P}_{\mathrm{R}}$ ) was premixed with $50 \mathrm{nM} \sigma^{70}$-containing E. coli RNA polymerase (Amersham) and different amounts of purified His $_{6}$ BzdR and benzoyl-CoA. For multiple-round assays, transcription was then initiated by adding a mixture of $500 \mathrm{nM}$ (each) ATP, CTP and GTP; $50 \mathrm{mM} \mathrm{UTP;} \mathrm{and} 2.5 \mu \mathrm{Ci}\left[\alpha_{-}{ }^{32} \mathrm{P}\right] \mathrm{UTP}\left(3000 \mathrm{mCi} \mathrm{mmol}^{-1}\right.$; $\left.111 \mathrm{GBq} \mathrm{mmol}^{-1}\right)$. After incubation for $15 \mathrm{~min}$ at $37^{\circ} \mathrm{C}$, the reactions were stopped with an equal volume of a solution containing $50 \mathrm{mM}$ EDTA, $350 \mathrm{mM} \mathrm{NaCl}$ and $0.5 \mathrm{mg}$ carrier tRNA ml${ }^{-1}$. The mRNA produced was then precipitated with ethanol, redissolved in loading buffer (7M urea, $1 \mathrm{mM}$ EDTA, $0.6 \mathrm{M}$ glycerol, $0.9 \mathrm{mM}$ bromophenol blue and $1.1 \mathrm{mM}$ xylene cyanol), electrophoresed on a denaturing $7 \mathrm{M}$ urea-4\% polyacrylamide gel, and visualized by autoradiography. Transcript levels were quantified with a Bio-Rad Molecular Imager FX system. The reactions were done using as a template pJCD01 plasmid derivatives, which enabled an internal control mRNA of $105 \mathrm{nt}$ to be obtained.

Primer extension analysis. Azoarcus sp. CIB cells harbouring plasmid $\mathrm{pBBR} 5 \mathrm{P}_{\mathrm{R}}\left(P_{R}\right.$ : : lac $\left.Z\right)$ were grown anaerobically on benzoatecontaining $\mathrm{MC}$ medium until the culture reached an $\mathrm{OD}_{600}$ of 0.3 . Total RNA was isolated by using an RNeasy Mini kit (Qiagen) according to the instructions of the supplier. Primer extension reactions were carried out with the avian myeloblastosis virus reverse transcriptase (Promega) and $10 \mu \mathrm{g}$ total RNA as described previously (Martín et al., 1996), using oligonucleotide Lac57 (5'-CGATTAAGTTGGGTAACGCCAGGG-3') labelled at its $5^{\prime}$-end with phage T4 polynucleotide kinase and $\left[\gamma_{-}{ }^{32} \mathrm{P}\right] \mathrm{ATP}\left(3000 \mathrm{Ci}, 111 \mathrm{TBq} \mathrm{mmol}^{-1}\right.$; Amersham Biosciences). To determine the length of the primer extension products, sequencing reactions of $\mathrm{pBBR} 5 \mathrm{P}_{\mathrm{R}}$ were carried out with oligonucleotide Lac57 using the T7 sequencing kit and $\left[\alpha^{32} \mathrm{P}\right] \mathrm{dCTP}$ (Amersham Biosciences) as indicated by the supplier. Products were analysed on $6 \%$ polyacrylamide-urea gels. The gels were dried onto Whatman 3MM paper and exposed to Hyperfilm MP (Amersham Biosciences).

Real-time RT-PCR assay. For this assay, RNA was extracted from Azoarcus sp. CIB cells grown on benzoate $(3 \mathrm{mM})$, succinate $(7.5 \mathrm{mM})$, or benzoate $(3 \mathrm{mM})$ plus succinate $(7.5 \mathrm{mM})$. Cells were harvested at the exponential phase of growth $\left(\mathrm{OD}_{600} 0.2\right)$ and stored at $-80{ }^{\circ} \mathrm{C}$. Pellets were thawed and cells lysed in TE buffer $(10 \mathrm{mM}$ Tris/ $\mathrm{HCl} \mathrm{pH} \mathrm{7.5,} 1 \mathrm{mM}$ EDTA) containing $5 \mathrm{mg}$ lysozyme $\mathrm{ml}^{-1}$ by a series of freeze/thaw cycles. RNA was extracted using the RNeasy Mini kit (Qiagen), including a DNase treatment according to the manufacturer's instructions, precipitated with ethanol, washed and resuspended in $40 \mu \mathrm{l}$ RNase-free water. The concentration and purity of the RNA samples were measured by using an ND1000 spectrophotometer (Nanodrop Technologies) according to the manufacturer's protocols. Analyses of the transcript levels from the $P_{N}$ or $P_{R}$ promoters were carried out with $20 \mu \mathrm{l}$ reverse transcription reactions containing $2 \mu \mathrm{g}$ RNA, $0.5 \mathrm{mM}$ of each dNTP, $200 \mathrm{U}$ SuperScript II reverse transcriptase (Invitrogen) and $0.5 \mu \mathrm{M}$ primer 3RTpN2 (5'-GTGTAGGTACACATCGTTGC-3') or 3RTpR2 (5'GAGGATGTCCAGGAAGGATTG-3'), respectively, in the buffer recommended by the manufacturer. The reactions were incubated at $42{ }^{\circ} \mathrm{C}$ for $2 \mathrm{~h}$, terminated by incubation at $70{ }^{\circ} \mathrm{C}$ for $15 \mathrm{~min}$, and the template RNA was removed by incubation at $37^{\circ} \mathrm{C}$ in the presence of $20 \mathrm{U}$ RNase $\mathrm{H}$ (Amersham Biosciences) for $20 \mathrm{~min}$. The cDNA obtained was stored at $-20{ }^{\circ} \mathrm{C}$. The IQ5 Multicolor Real-Time PCR Detection System (Bio-Rad) was used for real-time PCR in a $25 \mu \mathrm{l}$ reaction containing $10 \mu \mathrm{l}$ diluted cDNA, $0.2 \mu \mathrm{M}$ 3RTpR2 primer, $0.2 \mu \mathrm{M}$ 5RTpR1 primer (5'-GCTGTCATCGTGCTTCACG$\left.3^{\prime}\right)$ for the $P_{R}$ promoter, or $0.2 \mu \mathrm{M} 3 \mathrm{RTpN} 2$ primer, $0.2 \mu \mathrm{M} 5 \mathrm{RTpN} 1$ primer (5'-GCAACACATCAGAGGAGATAG-3') for the $P_{N}$ promoter, and $12.5 \mu \mathrm{l}$ SYBR Green mix (Applied Biosystems). PCR amplifications were carried out as follows: 1 initial cycle of denaturation $\left(95{ }^{\circ} \mathrm{C}\right.$ for $3 \mathrm{~min}$ ), followed by 44 cycles of amplification $\left(95{ }^{\circ} \mathrm{C}, 30 \mathrm{~s}\right.$; test annealing temperature, $57{ }^{\circ} \mathrm{C}, 30 \mathrm{~s}$; elongation and signal acquisition, $\left.72{ }^{\circ} \mathrm{C}, 30 \mathrm{~s}\right)$. For relative quantification of the fluorescence values, a calibration curve of serial dilutions of the genomic DNA sample was made.

\section{RESULTS AND DISCUSSION}

\section{BzdR auto-regulates its expression}

Transcriptional regulators governing the expression of catabolic promoters from aromatic catabolic pathways usually also control their own expression (Díaz \& Prieto, 2000; Tropel \& van der Meer, 2004). However, there appear to be no studies on the auto-regulation of transcriptional regulators controlling anaerobic aromatic pathways. To gain some knowledge on this topic, we checked whether the BzdR regulator from the anaerobic bzd cluster of Azoarcus sp. CIB also controls the activity of its own $P_{R}$ promoter. To accomplish this task, we fused the $P_{R}$ promoter to the lac $Z$ reporter gene to generate plasmid 
(a)

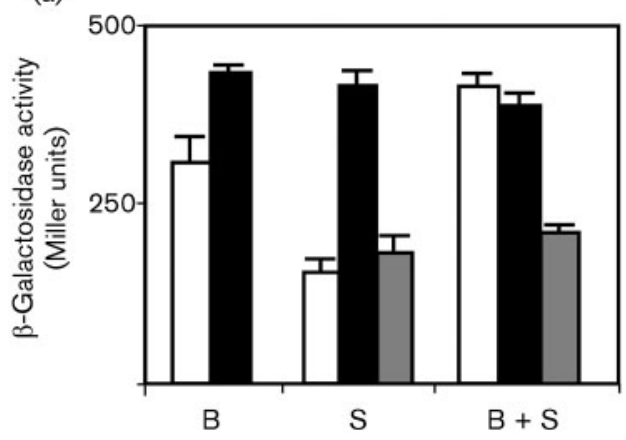

(b)

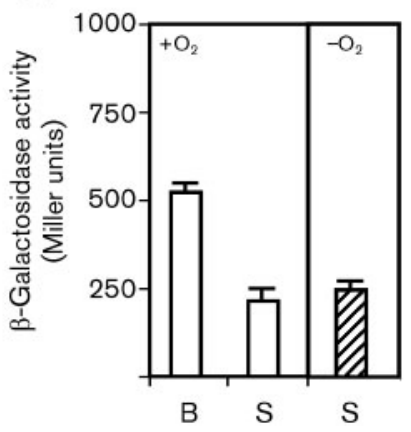

(c)

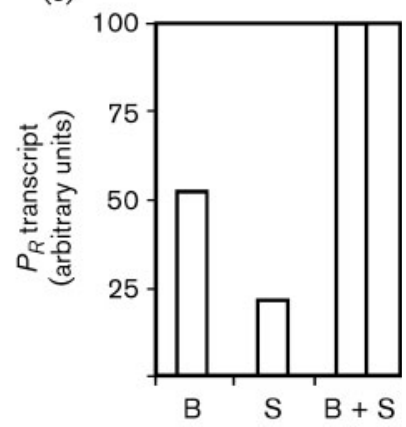

Fig. 2. Expression of the $b z d R$ gene under different growth conditions. (a) Activity of the $P_{R}$ promoter. $\beta$-Galactosidase activity of Azoarcus sp. CIB (white bars), Azoarcus sp. ClBdbzdR (black bars) and Azoarcus sp. ClBdbzdN (grey bars) cells harbouring plasmid $\mathrm{pBBR} 5 \mathrm{P}_{\mathrm{R}}\left(P_{R}:\right.$ : lacZ) was assayed. Cells were grown anaerobically until mid-exponential phase on $\mathrm{MC}$ medium containing $3 \mathrm{mM}$ benzoate $(B), 7.5 \mathrm{mM}$ succinate $(\mathrm{S})$, or $3 \mathrm{mM}$ benzoate plus $7.5 \mathrm{mM}$ succinate $(B+S)$. $\beta$ Galactosidase activity was measured as described in Methods. (b) $\beta$-Galactosidase activities of Azoarcus sp. CIB (white bars) or Azoarcus sp. ClBdacpR (hatched bars) cells grown aerobically $\left(+\mathrm{O}_{2}\right)$ or anaerobically $\left(-\mathrm{O}_{2}\right)$ until mid-exponential phase on MC medium containing $3 \mathrm{mM}$ benzoate (B) or $7.5 \mathrm{mM}$ succinate (S). (c) Activity of the $P_{R}$ promoter measured by real-time RTPCR was determined as detailed in Methods. Relative changes in the $P_{R}$ transcript level are indicated as percentages of the values obtained from cells growing on benzoate plus succinate. Error bars in (a) and (b) indicate standard deviations ( $n=3$ ).

pBBR5P $_{\mathrm{R}}$ (Table 1). We then analysed the $\beta$-galactosidase activity when Azoarcus sp. CIBd $b z d R$, a mutant strain carrying a disrupted $b z d R$ gene (Table 1), harbouring plasmid $\mathrm{pBBR} \mathrm{P}_{\mathrm{R}}\left(P_{R}::\right.$ lac $\left.Z\right)$, was grown on benzoate, succinate, or benzoate plus succinate as carbon sources. In all conditions tested, the $b z d R$ mutant cells showed similar levels of expression of the $P_{R}:$ : lac $Z$ fusion to those of the wild-type Azoarcus sp. CIB (pBBR5 $\left.P_{R}\right)$ growing on benzoate (induction conditions) (Fig. 2a), which suggests that the $b z d R$ gene product indeed behaves as a repressor of its own expression.

It has been shown before that benzoyl-CoA is the inducer molecule that relieves the repression of BzdR on the $P_{N}$ promoter (Barragán et al., 2005). To check whether benzoyl-CoA was also alleviating the BzdR-mediated repression of $P_{R}$, we monitored the expression of the $P_{R}:$ : lac $Z$ fusion in Azoarcus sp. CIBd $b z d N$, a mutant strain that is unable to grow anaerobically on benzoate and that does not form benzoyl-CoA because the expression of the entire transcriptional $b z d$ unit has been interrupted (López Barragán et al., 2004). Azoarcus sp. CIBdbzdN cells harbouring plasmid $\mathrm{pBBR} 5 \mathrm{P}_{\mathrm{R}}$ and grown on succinate or succinate plus benzoate showed the same levels of $P_{R}$ activity as the wild-type strain grown in the presence of succinate, and about twofold lower levels of $P_{R}$ activity than the wild-type strain grown in the presence of benzoate or benzoate plus succinate (Fig. 2a). These results, therefore, suggest that the repressor role of BzdR on the $P_{R}$ promoter becomes relieved when the cells grow in the presence of benzoate and benzoyl-CoA is formed.

To confirm in vitro the regulation of the $P_{R}$ promoter by the BzdR regulator, we first mapped the transcription start site of $P_{R}$ by primer extension analysis performed with total
RNA isolated from cells of Azoarcus sp. CIB $\left(\mathrm{pBBR} \mathrm{P}_{\mathrm{R}}\right)$ grown on benzoate. Transcription initiation was located $39 \mathrm{nt}$ upstream of the ATG translation initiation codon of the $b z d R$ gene (Fig. 3), showing putative -10 (CACTAT) and -35 (TTGCAA) boxes separated by 17 bp (Fig. 1) that match significantly the -10 (TATAAT) and -35

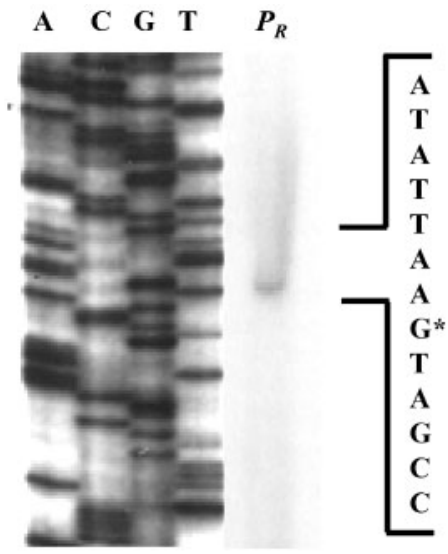

Fig. 3. Identification of the transcription start site in the $P_{R}$ promoter. Total mRNA was isolated from Azoarcus sp. CIB cells harbouring plasmid $\mathrm{pBBR} 5 \mathrm{P}_{\mathrm{R}}\left(P_{R}:: / a c Z\right)$, as described in Methods. The size of the extended product (lane $P_{R}$ ) was determined by comparison with the DNA sequencing ladder (lanes $\mathrm{A}, \mathrm{C}, \mathrm{G}$ and $\mathrm{T}$ ) of the $P_{R}$ promoter region. Primer extension and sequencing reactions were performed with primer Lac57 as described in Methods. An expanded view of the nucleotides surrounding the transcription initiation site (asterisk) in the noncoding strand is shown. 


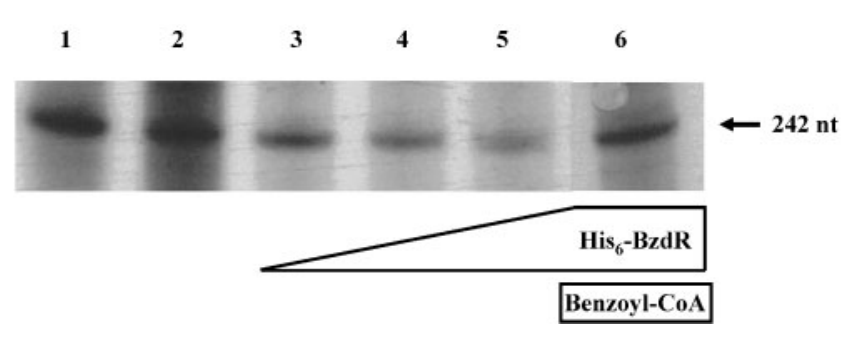

Fig. 4. In vitro activity of the $P_{R}$ promoter. Multiple-round in vitro transcription reactions were carried out by using $\mathrm{pJCD}-\mathrm{P}_{\mathrm{R}}$, a plasmid template that produces mRNA from $P_{R}$ of $242 \mathrm{nt}$. In vitro transcription reactions were performed with $50 \mathrm{nM}$ E. coli RNAP in the absence of $\mathrm{His}_{6}-\mathrm{BzdR}$ (lane 2), or in the presence of $50 \mathrm{nM}$ (lane 3), $100 \mathrm{nM}$ (lane 4) or $200 \mathrm{nM}$ (lane 5) purified His ${ }_{6}-\mathrm{BzdR}$. In lane $6,1 \mathrm{mM}$ benzoyl-CoA was added to the transcription reaction containing $200 \mathrm{nM}$ purified $\mathrm{His}_{6}-\mathrm{BzdR}$. Heat-inactivated $\mathrm{His}_{6}{ }^{-}$ BzdR $(200 \mathrm{nM})$ was added as a control to the transcription reaction (lane 1 ).

(TTGACA) consensus sequences recognized by the $\sigma^{70}$ subunit of RNA polymerase $\left(\sigma^{70}\right.$-RNAP). We then performed in vitro transcription assays using purified
His $_{6}$-BzdR protein, RNAP and plasmid pJCD- $\mathrm{P}_{\mathrm{R}}$, which contains a DNA fragment including the $P_{R}$ promoter (Table 1), as supercoiled DNA template. As shown in Fig. 4, the formation of the expected 242 nt transcript due to the activity of the $P_{R}$ promoter was inhibited by increasing concentrations of $\mathrm{His}_{6}-\mathrm{BzdR}$ (Fig. 4, lanes 3-5). In the presence of $200 \mathrm{nM} \mathrm{His}{ }_{6}-\mathrm{BzdR}$, the addition of benzoylCoA was able to increase the formation of the $P_{R}$ transcript (Fig. 4, lane 6), suggesting that this CoA derivative acts as an inducer avoiding the repression effect of BzdR. These results are in agreement with the previous lac $Z$ gene fusion experiments (see above), and they reveal a similar pattern of benzoyl-CoA-dependent induction of the BzdRmediated repression at both the $P_{R}$ and $P_{N}$ (Barragán et al., 2005) promoters from Azoarcus sp. CIB.

\section{Characterization of the $B z d R-P_{R}$ interaction}

To study the interaction of BzdR with the $P_{R}$ promoter, we first performed gel retardation assays with purified $\mathrm{His}_{6^{-}}$ BzdR protein and a $P_{R}$ probe spanning from position -169 to +120 of the $P_{R}$ promoter. The $\mathrm{His}_{6}-\mathrm{BzdR}$ protein bound to the $P_{R}$ promoter in a protein concentrationdependent manner (Fig. 5a), and this interaction was

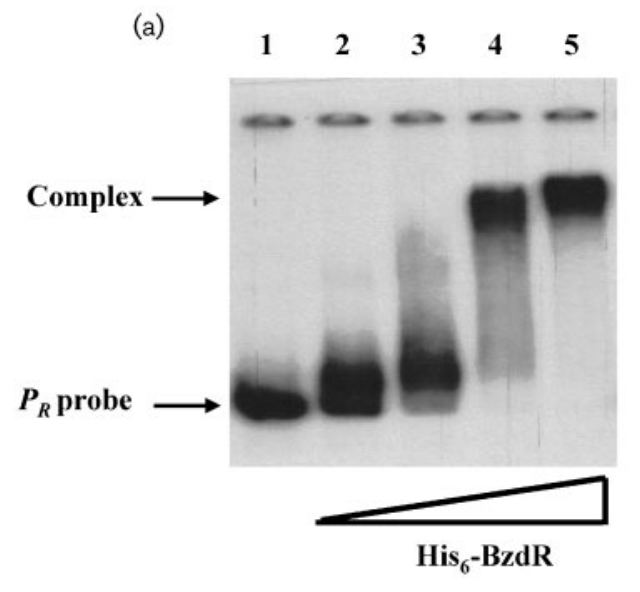

(b)

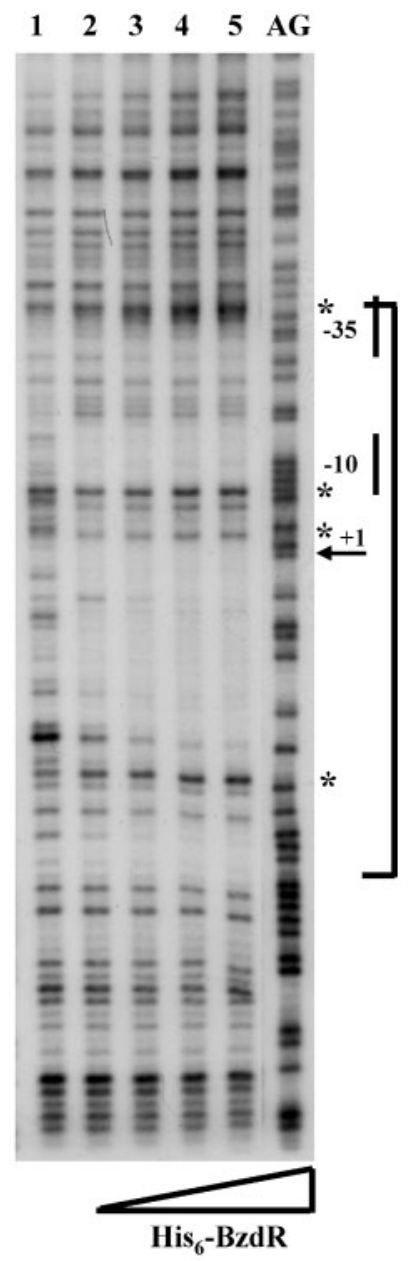

Fig. 5. In vitro analysis of the interaction of BzdR with the $P_{R}$ promoter. (a) Gel retardation analysis of $\mathrm{His}_{6}-\mathrm{BzdR}$ binding to the $P_{R}$ promoter, performed as indicated in Methods. Lane 1, free $P_{R}$ probe; lanes 2-5, retardation assays containing $0.05,0.1,0.5$ and $1 \mu \mathrm{M}$, respectively, of purified $\mathrm{His}_{6}-\mathrm{BzdR}$. The $P_{R}$ probe and the $P_{R}-$ BzdR complex are indicated by arrows. (b) DNase I footprinting analysis of the interaction of purified $\mathrm{His}_{6}-\mathrm{BzdR}$ with the $P_{R}$ promoter region. The experiments were carried out using the $P_{R}$ probe as indicated in Methods. Lane 1, footprinting assay in the absence of $\mathrm{His}_{6}-\mathrm{BzdR}$; lanes 2-5, footprinting assays containing $0.1,0.2,0.5$ and $1 \mu \mathrm{M}$ purified $\mathrm{His}_{6}-\mathrm{BzdR}$, respectively; lane $A G$, $A+G$ Maxam and Gilbert sequencing reaction. The protected region is marked by a bracket, and the phosphodiester bonds hypersensitive to DNase I cleavage are indicated by asterisks. The -10 and -35 boxes and the transcription initiation site $(+1)$ of the $P_{R}$ promoter are also shown. 
specific because it was inhibited by adding unlabelled $P_{R}$ probe and it was not affected by adding an unlabelled heterologous probe to the retardation assays (data not shown).

The BzdR operator at the $P_{R}$ promoter was identified by using DNase I footprinting assays. As shown in Fig. 5(b), the $\mathrm{His}_{6}$-BzdR protein protected a region spanning from position -33 to +25 of the $P_{R}$ promoter. Three direct GCAC repetitions and a short palindromic structure located 2 nt downstream of the +1 site were observed (Fig. 1). The fact that the operator of BzdR spans the transcription initiation site as well as the -10 and -35 boxes of $P_{R}$ (Figs 1 and $5 \mathrm{~b}$ ) is in agreement with the repressor role of BzdR on the activity of this promoter (see above). Since BzdR also overlaps the transcription initiation site as well as the -10 box at the catabolic $P_{N}$ promoter (Barragán et al., 2005), BzdR appears to act at both the $P_{R}$ and $P_{N}$ promoters using the same repression mechanism. Binding of BzdR to $P_{R}$ induces changes in the DNA structure as revealed by several phosphodiester bonds that become hypersensitive to DNase I cleavage (Fig. 5b). The same effect was also observed in the BzdR- $P_{N}$ interaction (Barragán et al., 2005). However, the binding affinity of BzdR to $P_{N}$ and $P_{R}$ promoters is quite different. Thus, whereas $50 \mathrm{nM}$ of purified $\mathrm{His}_{6}$-BzdR was needed to protect the $P_{N}$ promoter from DNase I digestion (Barragán et al., 2005), protection of the $P_{R}$ promoter was achieved with $0.5-1 \mu \mathrm{M}$ of purified regulator (Fig. $5 \mathrm{~b}$ ). This result is also in agreement with the moderate (Fig. 2) and high repression (Barragán et al., 2005) caused by BzdR at the $P_{R}$ and $P_{N}$ promoters, respectively. It should be noted that three BzdR operators were identified at the $P_{N}$ promoter, and all of them showed a direct repetition of the TGCA sequence forming part of a long palindromic operator structure (Barragán et al., 2005). This promoter architecture resembles that of promoters regulated by other members of the HTH-XRE family of transcriptional regulators such as the Cro and 434 repressors from the $\lambda$ and 434 phages, respectively, which also bind to short repeated sequences that, in most cases, are located within palindromic regions that span the promoters (Cervin et al., 1998; Koudelka \& Lam, 1993; Mandic-Mulec et al., 1995; Weickert \& Adhya, 1992). In contrast, only one BzdR operator, which contains a sole TGCA sequence located at the $5^{\prime}$-end (positions -32 to -29 ) of the protected region, was identified at the $P_{R}$ promoter. Therefore, the lower binding efficiency of BzdR to $P_{R}$ might reflect the different architecture of the $P_{N}$ and $P_{R}$ promoters.

\section{Role of oxygen and additional carbon sources in the expression of the bzdR gene}

Since the bzd genes are responsible for the anaerobic metabolism of benzoate in Azoarcus sp. CIB, the presence or absence of oxygen could play an essential role in the expression of such genes. In agreement with this, we have shown previously that the activity of the catabolic $P_{N}$ promoter is inhibited by oxygen (Durante-Rodríguez et al., 2006). To determine whether oxygen controls the expression of $P_{R}$, we checked the activity of the $P_{R}$ promoter driving the expression of the $b z d R$ gene when Azoarcus sp. CIB was cultivated in the presence or absence of oxygen. To this end, we determined the $\beta$-galactosidase activity in Azoarcus sp. $\mathrm{CIB}\left(\mathrm{pBBR} 5 \mathrm{P}_{\mathrm{R}}\right)$ cells that had reached, under aerobic or anaerobic conditions, mid-exponential growth phase on benzoate-containing minimal medium. As shown in Fig. 2(a, b), although the activity of the $P_{R}$ promoter was almost twofold higher in cells growing aerobically than in cells growing anaerobically, oxygen does not appear to play a major role in the expression of the $P_{R}$ promoter. To confirm this result, we checked the expression of the $P_{R}$ promoter in Azoarcus sp. CIBdacpR, a strain that harbours a disruption of the $a c p R$ gene required for the oxygendependent activity of the catabolic $P_{N}$ promoter and, therefore, unable to grow anaerobically on benzoate (Durante-Rodríguez et al., 2006). As shown in Fig. 2(b), the activity of the $P_{R}$ promoter in Azoarcus sp. CIBd $a c p R\left(\mathrm{pBBR} \mathrm{P}_{\mathrm{R}}\right)$ cells growing anaerobically on succinate-containing minimal medium was similar to that observed in Azoarcus sp. $\mathrm{CIB}\left(\mathrm{pBBR} 5 \mathrm{P}_{\mathrm{R}}\right)$ cells. Moreover, Western-blotting experiments using anti-BzdR antibodies revealed that the levels of BzdR protein in crude extracts of Azoarcus sp. CIB cells grown either aerobically or anaerobically were similar (data not shown). All these results taken together indicate that the $P_{R}$ promoter is not subject to the AcpR/oxygen-dependent superimposed regulation that controls the activity of the catabolic $P_{N}$ promoter in Azoarcus sp. CIB. The aerobic expression of the $b z d R$ gene might contribute to the lack of expression of the bzd catabolic operon when the cells grow in the presence of oxygen, thus avoiding the production of some oxygen-sensitive enzymes such as benzoyl-CoA reductase (BzdNOPQ) (López Barragán et al., 2004).

The simultaneous presence of different carbon sources plays a major role in the superimposed regulation of aromatic catabolic clusters (Cases \& de Lorenzo, 2005; Díaz \& Prieto, 2000; Carmona et al., 2008). Whereas carbon catabolite repression of regulatory genes has been reported in aerobic degradation pathways (Canosa et al., 2000; Müller et al., 1996), such superimposed regulation of regulatory genes controlling aromatic anaerobic clusters has not been studied so far. As shown in Fig. 2(a), the activity of the $P_{R}$ promoter in Azoarcus sp. CIB(pBBR5P $\mathrm{P}_{\mathrm{R}}$ ) was almost twofold higher when the cells were grown on benzoate or benzoate plus succinate than when they were grown on succinate as sole carbon source. Therefore, in contrast to what had been observed for the bzd catabolic genes, whose expression becomes significantly reduced when the cells grow in the presence of benzoate and an additional carbon source such as succinate (López Barragán et al., 2004), the expression of the $b z d R$ gene does not decrease when succinate is provided as an additional carbon source. To confirm that the activity levels of the $P_{R}:$ lac $Z$ fusion are indeed the result of the 
transcriptional activity of the $P_{R}$ promoter and are not due to a possible post-transcriptional regulation of the $l a c Z$ gene, we performed real-time RT-PCR experiments to monitor the $P_{R}$ transcript levels directly. The results obtained using RNAs isolated from Azoarcus sp. CIB cells grown on succinate, benzoate or succinate plus benzoate were in good agreement with those reported by $\beta$ galactosidase assays with the $P_{R}$ : : lacZ fusion (Fig. 2c). Therefore, all these results indicate that the expression of the $b z d R$ gene is not subject to catabolite repression by organic acids, such as succinate, in Azoarcus sp. CIB.

\section{BzdR is required for the catabolite repression of the bzd catabolic operon}

As previously reported for Azoarcus sp. CIBlacZ, a strain that contains the $P_{N}$ : : lac $Z$ translational fusion integrated into its chromosome, the $P_{N}$ promoter is subject to carbon catabolite repression by some organic acids such as succinate, malate and acetate (López Barragán et al., 2004). Whereas the molecular basis of the carbon catabolite repression has been studied in some aromatic aerobic clusters, there are no data on the factor(s) involved in catabolite repression of aromatic anaerobic clusters. To try to identify some of the factors involved in such catabolite repression, we analysed the expression of the $P_{N}$ : :lac $Z$ translational fusion in Azoarcus sp. CIB and Azoarcus sp. CIBd $b z d R$ strains harbouring plasmid pBBR5P $_{\mathrm{N}}$ $\left(P_{N}:\right.$ :lac $Z$ ) (Table 1$)$. As expected, the $\beta$-galactosidase activity levels in Azoarcus sp. $\mathrm{CIB}\left(\mathrm{pBBR} 5 \mathrm{P}_{\mathrm{N}}\right)$ cells grown anaerobically in the presence of benzoate plus succinate were threefold lower than those obtained in cells grown on benzoate as the sole carbon source (Fig. 6a), which confirms the observed catabolite repression exerted by succinate at the $P_{N}$ promoter when expressing the $P_{N}$ : : lacZ fusion from the chromosome (López Barragán et al., 2004). However, it is interesting to note a stronger catabolite repression (about 500-fold repression) using the chromosome-inserted $P_{N}$ : : lacZ fusion (López Barragán et al., 2004), suggesting that the element(s) responsible for the catabolite repression is present in Azoarcus sp. CIB at a concentration that cannot overcome the multicopy dosage effect of the $P_{N}$ : : lac $Z$ fusion in plasmid $\mathrm{pBBR} \mathrm{P}_{\mathrm{N}}$. To confirm that the activity levels of the $P_{N}$ : : lac $Z$ fusion are indeed the result of the transcriptional activity of the $P_{N}$ promoter and they are not due to a possible posttranscriptional regulation of the lac $Z$ gene, we performed real-time RT-PCR experiments to monitor the $P_{N}$ transcript levels directly. The results obtained using RNAs isolated from Azoarcus sp. CIB cells grown on succinate, benzoate or succinate plus benzoate were in good agreement with those reported by $\beta$-galactosidase assays with the $P_{N}$ : : lac $Z$ fusion, and they confirmed that the catabolite repression caused by succinate on the $P_{N}$ promoter is exerted at the transcriptional level (Fig. 6b).

Interestingly, the $\beta$-galactosidase activity levels in Azoarcus sp. CIBd $b z d R\left(\operatorname{pBBR} \mathrm{P}_{\mathrm{N}}\right)$ cells grown in the presence of (a)

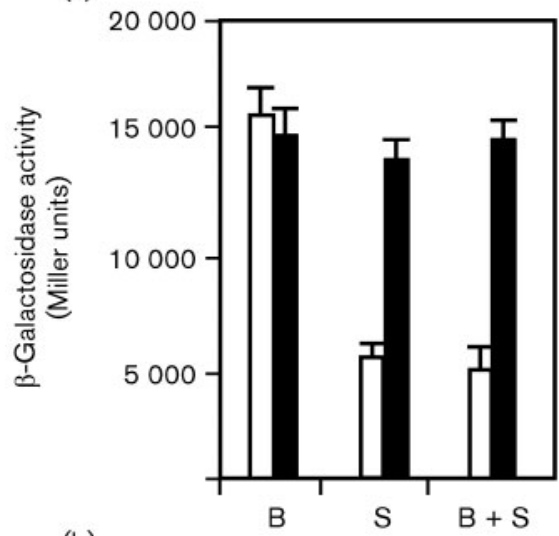

(b)

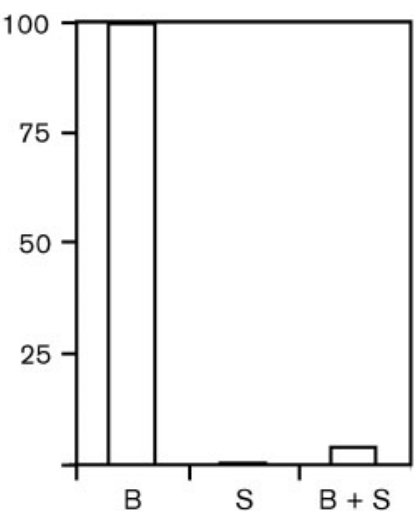

Fig. 6. In vivo activity of the $P_{N}$ promoter. Azoarcus sp. CIB cells were grown anaerobically on $\mathrm{MC}$ medium containing $3 \mathrm{mM}$ benzoate (B), $7.5 \mathrm{mM}$ succinate (S), or a mixture of $3 \mathrm{mM}$ benzoate and $7.5 \mathrm{mM}$ succinate $(B+S)$, until the cultures reached mid-exponential phase. (a) Expression of the $P_{N}$ : : lacZ reporter fusion. $\beta$-Galactosidase activity of Azoarcus sp. CIB (white bars) or Azoarcus sp. CIBdbzdR (black bars) cells harbouring plasmid pBBR5P $_{N}\left(P_{N}\right.$ : : lac $\left.Z\right)$ was assayed as described in Methods. Error bars indicate standard deviations $(n=3)$. (b) Activity of the $P_{N}$ promoter measured by real-time RT-PCR. Total RNA was obtained from Azoarcus sp. CIB cultures, and real-time RT-PCR was performed as detailed in Methods. Relative changes in the $P_{N}$ transcript levels are indicated as percentages of the values obtained from cells growing on benzoate. The results of one experiment are shown, and the values were reproducible in three separate experiments with standard deviations of $<10 \%$ of the mean.

benzoate plus succinate were similar to those obtained with cells grown on benzoate (Fig. 6a). Moreover, when the cells were grown under non-inducing conditions, i.e. in the presence of succinate as sole carbon source, the expression of the $P_{N}$ : :lacZ fusion in Azoarcus sp. CIBd $b z d R\left(\mathrm{pBBR} \mathrm{P}_{\mathrm{N}}\right)$ was similar to that observed in wild-type Azoarcus sp. $\mathrm{CIB}\left(\mathrm{pBBR} 5 \mathrm{P}_{\mathrm{N}}\right)$ cells growing in the presence of benzoate (Fig. 6a). All these data taken together indicate that the inactivated BzdR relieves the catabolite repression exerted by succinate at the $P_{N}$ promoter. 


\section{Concluding remarks}

There are several reports showing that the downregulation of promoters from catabolic pathways when the cells grow in the presence of the particular substrate and a preferred carbon source is mediated by shifting the levels of the cognate transcriptional regulators. Thus, catabolite repression of the alkane degradation pathway (alk genes) encoded in the OCT plasmid from Pseudomonas putida strain GPo1 parallels a decrease of the expression of the AlkS activator (Canosa et al., 2000). Similarly, catabolite repression of phenol degradation (phl genes) in P. putida strain $\mathrm{H}$ occurs by interfering with the activating function of the PhlR transcriptional regulator (Müller et al., 1996). In this work, however, we show that a specific transcriptional regulator whose expression is not subject to catabolite repression (see above) mediates the catabolite repression of the cognate catabolic operon. Moreover, our results suggest the existence of additional factors that, together with BzdR, might account for the molecular basis of the catabolite repression of the anaerobic benzoate degradation pathway in Azoarcus sp. CIB. A possible scenario for catabolite repression that would explain our results is that BzdR might recruit an additional regulatory factor that binds to the $P_{N}$ promoter in response to succinate, thus preventing the basal levels of $b z d$ readthrough that allow the effector benzoyl-CoA to be generated. In this context, proteins such as Crc (catabolite repression control) (Morales et al., 2004), PtsN and PtsO (nitrogen phosphotransferase system) (Aranda-Olmedo et al., 2005, 2006; Cases \& de Lorenzo, 2005; Marqués et al., 2006), and some o-type terminal oxidases (Cyo) that sense the redox state of the cell (Rojo \& Dinamarca, 2004; Morales et al., 2006; Petruschka et al., 2001) have been reported to be involved in catabolite repression of several aromatic degradation pathways in Pseudomonas. Recently, a response regulator (BphQ) of a two-component regulatory system was shown to control catabolite repression of the $b p h$ operon for the degradation of polychlorobiphenyl/biphenyl in the $\beta$-proteobacterium Acidovorax sp. KKS102 (Ohtsubo et al., 2006). Orthologues of these carbon-repression mediators have been found in the genome of Azoarcus sp. EbN1, another Azoarcus strain that degrades aromatic compounds and whose complete genome is known (Rabus et al., 2005). Thus, Azoarcus sp. EbN1 has an orthologue of the Crc (EbA3323), CRP (EbA7043), PtsN/ PtsO (EbA27937/EbA2794) and BphQ (EbA125) proteins, as well as three orthologues of the $\mathrm{CyoB}$ protein (EbA4228, EbA156 and EbA4554). The involvement of all or some of these proteins in carbon catabolite repression in Azoarcus sp. CIB, and the molecular mechanisms underlying the role of BzdR in the carbon catabolite repression, will be explored in future work and will allow us to increase our current view on the superimposed regulation of the $b z d$ gene cluster, so far the best-studied regulatory system in anaerobic catabolism of aromatic compounds.

\section{ACKNOWLEDGEMENTS}

This work was supported by Comunidad Autónoma de Madrid Grant P-AMB-259-0505, and Comisión Interministerial de Ciencia y Tecnología grants BIO2003-01482, BIO2006-05957, VEM200320075-CO2-02 and GEN2006-27750-C5-3-E/SYS. G.D.-R. is the recipient of a predoctoral fellowship from the Plan Nacional de Formación de Personal Investigador-MEC. M. C. is a holder of the Ramón y Cajal Program of the Spanish Ministerio de Educación y Ciencia. The technical work of M. Morales, M. Zazo and A. Valencia is greatly appreciated. The help of A. Díaz, S. Carbajo and M. Cayuela with sequencing is gratefully acknowledged.

\section{REFERENCES}

Altschul, S. F., Gish, W., Miller, E., Myers, W. \& Lipman, D. J. (1990). Basic local alignment search tool. J Mol Biol 215, 403-410.

Aranda-Olmedo, I., Ramos, J. L. \& Marqués, S. (2005). Integration of signals through $\mathrm{Crc}$ and PtsN in catabolite repression of Pseudomonas putida TOL plasmid pWW0. Appl Environ Microbiol 71, 4191-4198.

Aranda-Olmedo, I., Marín, P., Ramos, J. L. \& Marqués, S. (2006). Role of the $p t s N$ gene product in catabolite repression of the Pseudomonas putida TOL toluene degradation pathway in chemostat cultures. Appl Environ Microbiol 72, 7418-7421.

Barragán, M. J. L., Blázquez, B., Zamarro, M. T., Mancheño, J. M., Garcia, J. L., Díaz, E. \& Carmona, M. (2005). BzdR, a repressor that controls the anaerobic catabolism of benzoate in Azoarcus sp. CIB, is the first member of a new subfamily of transcriptional regulators. J Biol Chem 280, 10683-10694.

Boll, M. (2005). Key enzymes in the anaerobic aromatic metabolism catalysing Birch-like reductions. Biochim Biophys Acta 1707, 34-50.

Bradford, M. M. (1976). A rapid and sensitive method for the quantitation of microgram quantities of protein utilizing the principle of protein-dye binding. Anal Biochem 72, 248-254.

Canosa, I., Sánchez-Romero, J. M., Yuste, L. \& Rojo, F. (2000). A positive feedback mechanism controls expression of AlkS, the transcriptional regulator of the Pseudomonas oleovorans alkane degradation pathway. Mol Microbiol 35, 791-799.

Carmona, M. \& Díaz, E. (2005). Iron-reducing bacteria unravel novel strategies for the anaerobic catabolism of aromatic compounds. $\mathrm{Mol}$ Microbiol 58, 1210-1215.

Carmona, M. \& Magasanik, B. (1996). Activation of transcription at sigma 54-dependent promoters on linear templates requires intrinsic or induced bending of the DNA. J Mol Biol 261, 348-356.

Carmona, M., Prieto, M. A., Galán, B., García, J. L. \& Díaz, E. (2008). Signaling networks and design of pollutant biosensors. In Microbial Biodegradation: Genomics and Molecular Biology, pp. 97-142. Edited by E. Díaz. London, UK: Horizon Scientific Press.

Cases, I. \& de Lorenzo, V. (1998). Expression systems and physiological control of promoter activity in bacteria. Curr Opin Microbiol 1, 303-310.

Cases, I. \& de Lorenzo, V. (2005). Promoters in the environment: transcriptional regulation in its natural context. Nat Rev Microbiol 3, 105-118.

Cervin, M. A., Lewis, R. J., Brannigan, J. A. \& Spiegelman, G. B. (1998). The Bacillus subtilis regulator $\operatorname{SinR}$ inhibits spoIIG promoter transcription in vitro without displacing RNA polymerase. Nucleic Acids Res 26, 3806-3812.

Collier, D. N., Hager, P. W. \& Phibbs, P. V., Jr (1996). The Bacillus subtilis regulator SinR inhibits spoIIG promoter transcription in vitro without displacing RNA polymerase. Res Microbiol 147, 551-561. 
de Lorenzo, V. \& Timmis, K. N. (1994). Analysis and construction of stable phenotypes in gram-negative bacteria with Tn5- and Tn10derived minitransposons. Methods Enzymol 235, 386-405.

Díaz, E. \& Prieto, M. A. (2000). Bacterial promoters triggering biodegradation of aromatic pollutants. Curr Opin Biotechnol 11, 467-475.

Durante-Rodríguez, G., Zamarro, M. T., Garcia, J. L., Díaz, E. \& Carmona, M. (2006). Oxygen-dependent regulation of the central pathway for the anaerobic catabolism of aromatic compounds in Azoarcus sp. strain CIB. J Bacteriol 188, 2343-2354.

Egland, P. G. \& Harwood, C. S. (1999). BadR, a new MarR family member, regulates anaerobic benzoate degradation by Rhodopseudomonas palustris in concert with AadR, an Fnr family member. J Bacteriol 181, 2102-2109.

Egland, P. G. \& Harwood, C. S. (2000). HbaR, a 4-hydroxybenzoate sensor and FNR-CRP superfamily member, regulates anaerobic 4hydroxybenzoate degradation by Rhodopseudomonas palustris. J Bacteriol 182, 100-106.

Elshahed, M. S., Bhupathiraju, V. K., Wofford, N. Q., Nanny, M. A. \& Mclnerney, M. J. (2001). Metabolism of benzoate, cyclohex-1-ene carboxylate, and cyclohexane carboxylate by "Syntrophus aciditrophicus" strain SB in syntrophic association with $\mathrm{H}_{2}$-using microorganisms. Appl Environ Microbiol 67, 1728-1738.

Gibson, J. \& Harwood, C. S. (2002). Metabolic diversity in aromatic compound utilization by anaerobic microbes. Annu Rev Microbiol 56 345-369.

Harwood, C. S. \& Parales, R. E. (1996). The $\beta$-ketoadipate pathway and the biology of self-identity. Annu Rev Microbiol 50, 553-590.

Harwood, C. S., Burchhardt, G., Herrmann, H. \& Fuchs, G. (1999). Genetic clues on the evolution of anaerobic catabolism of aromatic compounds. FEMS Microbiol Rev 22, 439-458.

Heider, J., Boll, M., Breese, K., Breinig, S., Ebenau-Jehle, C., Feil, U., Gad'on, N., Laempe, D., Leuthner, B. \& other authors (1998). Differential induction of enzymes involved in anaerobic metabolism of aromatic compounds in the denitrifying bacterium Thauera aromatica. Arch Microbiol 170, 120-131.

Jahn, M. K., Haderlein, S. B. \& Meckenstock, R. U. (2005). Anaerobic degradation of benzene, toluene, ethylbenzene, and $o$-xylene in sediment-free iron-reducing enrichment cultures. Appl Environ Microbiol 71, 3355-3358.

Koudelka, G. B. \& Lam, C. Y. (1993). Differential recognition of OR1 and OR3 by bacteriophage 434 repressor and Cro. J Biol Chem 268, 23812-23817.

Kovach, M. E., Elzer, P. H., Hills, D. S., Robertson, G. T., Farris, M. A., Roop, R. M., II \& Peterson, K. M. (1995). Four new derivatives of the broad-host-range cloning vector pBBR1MCS, carrying different antibiotic-resistance cassettes. Gene 166, 175-176.

Laemmli, U. K. (1970). Cleavage of structural proteins during the assembly of the head of bacteriophage T4. Nature 227, 680-685.

López Barragán, M. J., Carmona, M., Zamarro, M. T., Thiele, B., Boll, M., Fuchs, G., García, J. L. \& Díaz, E. (2004). The bzd gene cluster, coding for anaerobic benzoate catabolism, in Azoarcus sp. strain CIB. J Bacteriol 186, 5762-5774.

Lovley, D. R. (2003). Cleaning up with genomics: applying molecular biology to bioremediation. Nat Rev Microbiol 1, 35-44.

Magasanik, B. (1970). Glucose effects: inducer exclusion and repression. In The Lactose Operon, pp. 189-220. Cold Spring Harbor, NY: Cold Spring Harbor Laboratory.

Mandic-Mulec, I., Doukhan, L. \& Smith, I. (1995). The Bacillus subtilis SinR protein is a repressor of the key sporulation gene spo0A. J Bacteriol 177, 4619-4627.
Marqués, S., Aranda-Olmedo, I. \& Ramos, J. L. (2006). Controlling bacterial physiology for optimal expression of gene reporter constructs. Curr Opin Biotechnol 17, 50-52.

Marschall, C., Labrousse, V., Kreimer, M., Weichart, D., Kolb, A. \& Hengge-Aronis, R. (1998). Molecular analysis of the regulation of csiD, a carbon starvation-inducible gene in Escherichia coli that is exclusively dependent on $\sigma^{\mathrm{s}}$ and requires activation by cAMP-CRP. $J$ Mol Biol 276, 339-353.

Martín, A. C., López, R. \& García, P. (1996). Analysis of the complete nucleotide sequence and functional organization of the genome of Streptococcus pneumoniae bacteriophage Cp-1. J Virol 70, 3678-3687.

Maxam, A. M. \& Gilbert, W. (1980). Sequencing end-labeled DNA with base-specific chemical cleavages. Methods Enzymol 65, 499-560.

Miller, J. H. (1972). Experiments in Molecular Genetics. Cold Spring Harbor, NY: Cold Spring Harbor Laboratory.

Morales, G., Linares, J. F., Beloso, A., Albar, J. P., Martínez, J. L. \& Rojo, F. (2004). The Pseudomonas putida Crc global regulator controls the expression of genes from several chromosomal catabolic pathways for aromatic compounds. J Bacteriol 186, 1337-1344.

Morales, G., Ugidos, A. \& Rojo, F. (2006). Inactivation of the Pseudomonas putida cytochrome $o$ ubiquinol oxidase leads to a significant change in the transcriptome and to increased expression of the CIO and Cbb3-1 terminal oxidases. Environ Microbiol 8, 1764-1774.

Müller, C., Petruschka, L., Cuypers, H., Burchhardt, G. \& Herrmann, H. (1996). Carbon catabolite repression of phenol degradation in Pseudomonas putida is mediated by the inhibition of the activator protein PhlR. J Bacteriol 178, 2030-2036.

Ohtsubo, Y., Goto, H., Nagata, Y., Kudo, T. \& Tsuda, M. (2006). Identification of a reponse regulator gene for catabolite control from a PCB-degrading beta-proteobacterium, Acidovorax sp. KKS102. Mol Microbiol 60, 1563-1575.

Peres, C. M. \& Harwood, C. S. (2006). BadM is a transcriptional repressor and one of three regulators that control benzoyl coenzyme A reductase gene expression in Rhodopseudomonas palustris. J Bacteriol 188, 8662-8665.

Peters, F., Rother, M. \& Boll, M. (2004). Selenocysteine-containing proteins in anaerobic benzoate metabolism of Desulfococcus multivorans. J Bacteriol 186, 2156-2163.

Peters, F., Shinoda, Y., Mclnerney, M. J. \& Boll, M. (2007). Cyclohexa1,5-diene-1-carbonyl-coenzyme A (CoA) hydratases of Geobacter metallireducens and Syntrophus aciditrophicus: evidence for a common benzoyl-CoA degradation pathway in facultative and strict anaerobes. J Bacteriol 189, 1055-1060.

Petruschka, L., Burchhardt, G., Müller, C., Weihe, C. \& Herrmann, H. (2001). The cyo operon of Pseudomonas putida is involved in catabolic repression of phenol degradation. Mol Genet Genomics 266, 199-206.

Prieto, M. A., Galán, B., Torres, B., Ferrández, A., Fernández, C., Miñambres, B., García, J. L. \& Díaz, E. (2004). Aromatic metabolism versus carbon availability: the regulatory network that controls catabolism of less-preferred carbon sources in Escherichia coli. FEMS Microbiol Rev 28, 503-518.

Rabus, R., Kube, M., Heider, J., Beck, A., Heitmann, K., Widdel, F. \& Reinhardt, R. (2005). The genome sequence of an anaerobic aromaticdegrading denitrifying bacterium, strain EbN1. Arch Microbiol 183, 27-36.

Rojo, F. \& Dinamarca, M. A. (2004). Catabolite repression and physiological control. In Pseudomonas, vol. 2, pp. 365-387. Edited by J. L. Ramos. New York: Kluwer.

Safinowski, M., Griebler, C. \& Meckenstock, R. U. (2006). Anaerobic cometabolism transformation of polycyclic and heterocyclic aromatic hydrocarbons: evidence from laboratory and field studies. Environ Sci Technol 40, 4165-4173. 
Sambrook, J. W. \& Russell, D. W. (2001). Molecular Cloning: a Laboratory Manual, 3rd edn. Cold Spring Harbor, NY: Cold Spring Harbor Laboratory.

Song, B. \& Ward, B. B. (2005). Genetic diversity of benzoyl coenzyme A reductase genes detected in denitrifying isolates and estuarine sediment communities. Appl Environ Microbiol 71, 2036-2045.

Tropel, D. \& van der Meer, J. R. (2004). Bacterial transcriptional regulators for degradation pathways of aromatic compounds. Microbiol Mol Biol Rev 68, 474-500.
Weickert, M. J. \& Adhya, S. (1992). A family of bacterial regulators homologous to Gal and Lac repressors. J Biol Chem 267, 15869-15874.

Wischgoll, S., Heintz, D., Peters, F., Erxleben, A., Sarnighausen, E., Reski, R., van Dorsselaer, A. \& Boll, M. (2005). Gene clusters involved in anaerobic benzoate degradation of Geobacter metallireducens. Mol Microbiol 58, 1238-1252.

Edited by: M. A. Kertesz 